\title{
Akibat Hukum Penetapan Hak Waris Dan Hak Asuh Anak Oleh Hakim Pengadilan Negeri: Studi Putusan Nomor 282/Pdt.G/2014/Pn.Tng
}

\author{
Heru Siswanto ${ }^{1}$, Elfirda Ade Putri ${ }^{2}$ \\ ${ }^{12}$ Fakultas Hukum, Universitas Bhayangkara Jakarta Raya \\ Email: elfirdade.putri@gmail.com
}

Received : 20 Oct 2021 | Revised : 24 Nop 2021 | Accepted : 3 Dec 2021 | Published : 9 Dec 2021

\begin{abstract}
Divorce causes various problems, one of which is the issue of determining child custody. In terms of determining child custody there are no definite rules regarding where the child will be anchored after the divorce, because Law No. 1 of 1974 concerning Marriage and Law No. 35 of 2014 concerning Child Protection do not regulate to whom the child is. Later, they will be cared for by both the father and mother. In child custody cases, the panel of judges usually refers to Jurisprudence and the Compilation of Islamic Law, but in one case there is something unique in the judge's decision which is more directed towards customary law so that it overrides these two things which are usually a reference in determining child custody. . So this is very important considering that in a problem the determination of child custody does not end after a court decision but how the parents who get the determination of child custody can fulfill especially the problem of fulfilling the rights and obligations of the child itself. Because it can be seen that children are victims of a divorce.
\end{abstract}

Keywords: Child, Marriage, Marriage

\begin{abstract}
ABSTRAK
Perceraian menimbulkan berbagai masalah salah satunya adalah mengenai permasalahan penetapan hak asuh anak. Dalam hal mengenai penetapan hak asuh anak tidak adanya aturan yang pasti mengenai kemana anak akan berlabuh setelah terjadinya perceraian tersebut, karena di dalam Undang-Undang No 1 Tahun 1974 tentang Perkawinan dan Undang-Undang No 35 Tahun 2014 Tentang Perlindungan Anak tidak mengatur kepada siapa anak nantinya akan di asuh baik itu kepada pihak ayah maupun ibu. Pada perkara hak asuh anak biasanya majelis hakim mengacu kepada Yurisprudensi dan Kompilasi Hukum Islam tetapi dalam salah satu perkara ada suatu hal yang unik dalam putusan majelis hakim yang lebih mengarah ke arah hukum adat sehingga mengesampingkan dua hal tersebut yang biasanya menjadi acuan dalam penetapan hak asuh anak. Sehingga hal ini sangatlah penting mengingat bahwa dalam suatu masalah penetapan hak asuh anak tidak berakhir setelah adanya putusan pengadilan tetapi bagaimana orang tua yang mendapatkan penetapan hak asuh anak tersebut dapat memenuhi
\end{abstract}


khususnya masalah pemenuhan hak dan kewajiban terhadap anak itu sendiri. Karena dapat dilihat bahwa anak adalah sebagai korban dari suatu perceraian.

Kata Kunci: Anak, Perkawinan, Perkawinan

\section{PENDAHULUAN}

Sejak diberlakukannya Undang-undang Nomor 1 Tahun 1974 tentang Perkawinan, yang berlaku untuk seluruh rakyat Indonesia dan di seluruh wilayah Indonesia, maka sejak itulah setiap perkawinan harus didasarkan pada Undang-undang Nomor 1 Tahun 1974 serta peraturan pelaksanaannya dan semua peraturan yang mengatur tentang perkawinan sejauh telah diatur dalam undang-undang ini dinyatakan tidak berlaku lagi. ${ }^{1}$ Bagi orang Batak Kristen pernikahan bukan hanya sekedar mempersatukan dua insan yang telah membentuk rumah tangga yang baru, melainkan juga mempersatukan dalam tatanan 2 keluarga besar yakni keluarga besar (marga) mempelai pria dn keluarga besar (marga) mempelai wanita.

Dalam kenyataannya tidak semua perkawinan dapat berlangsung dengan langgeng dan tentunya tidak ada seorang pun yang ingin perkawinannya berakhir dengan jalan perceraian. Namun dalam pergaulan antara suami istri tidak jarang terjadi perselisihan dan pertengkaran yang terus menerus, maupun sebab-sebab lain yang kadang-kadang menimbulkan suatu keadaan yang menyebabkan suatu perkawinan tidak dapat dipertahankan lagi, sedangkan upaya-upaya damai yang dilakukan oleh kedua belah pihak maupun keluarga tidak membawa hasil yang maksimal sehingga pada akhirnya jalan keluar yang harus ditempuh tidak lain adalah perceraian. Dalam adat Batak Toba kata cerai disebut sirang. Kata sirang atau marsirang dikenal sebagai terjemahan cerai atau bercerai. Arti asli kata sirang adalah lepas. Ada juga kata dipaulak yang artinya dipulangkan atau dikembalikan. Dalam hal ini isteri dipulangkan kepada orang tuanya. Adapun alasan perceraian dalam adat yang diperbolehkan diantaranya adalah adanya pertengkaran antara suami/istri secara terus menerus, dan karena tidak memiliki keturunan. ${ }^{2}$ Menurut Undang-undang No.1 Tahun 1974, perceraian adalah salah satu bentuk dari sebab putusnya perkawinan. Dengan putusnya suatu perkawinan berdasarkan putusan pengadilan yang telah berkekuatan hukum tetap (inkracht van gewijsde), maka akan ada akibat hukum yang mengikutinya, salah satunya adalah mengenai Hak Asuh atas anak yang lahir dari perkawinan tersebut. Hak adalah wewenang yang diberikan hukum kepada subjek hukum $^{3}$. Hak asuh setelah terjadi perceraian, salah satu pihak mungkin ada yang merasa lebih berhak untuk mengasuh anak-anaknya. Baik itu ibunya, karena merasa ia yang mengandung dan melahirkan, atau ayahnya, karena merasa ia yang membiayai. Akibat hukum terhadap anak ialah apabila terjadi perceraian, maka baik ayah atau ibu tetap berkewajiban memelihara dan mendidik anak anaknya, sematamata berdasarkan kepentingan anak, bilamana terjadi perselisihan mengenai penguasaan anak-anak, Pengadilan memberikan keputusannya. ${ }^{4}$ Pada umumnya jika terjadi perceraian pada masyarakat Batak hak asuh anak akan jatuh ketanangan

\footnotetext{
${ }^{1}$ Sajuti Thalib, Hukum Keluarga Indonesia, (Jakarta : Universitas Indonesia, 1986), hlm. 47

2 https://media.neliti.com/media/publications/162641-ID-perlindungan-hukum-terhadapanak-di-bawa.pdf

${ }^{3}$ Hasanuddin AF, Pengantar Ilmu Hukum (Jakarta: Pustaka Al-Husna Baru, 2004), hlm. 86.

${ }^{4}$ Hilman Hadikusuma, Hukum Perkawinan Indonesia Menurut: Perundangan, Hukum Adat,Hukum Agama (Bandung: Mandar Maju,1990), 188-189.
} 
ayahnya, hal ini di sebabkan masyarakat Batak Toba menganut sistem patrilineal dimana anak-anak akan menjadi penerus marga ayahnya, tetapi dalam hal terdapat masih balita (masih menyusui) maka hak pengasuhannya akan diberikan kepada ibunya hal ini dilakukan karena ibu dianggap sebagai orang yang paling mengetahui dan memahami keadaan dan perkembangan anaknya. Namun berdasarkan hasil penelitian dalam perkembangan masyarakat adat Batak, ternyata tidak selamanya pengasuhan anak diberikan kepada ayahnya, anak dibawah umur diberikan kebebasan untuk menentukan dengan siapa dia diasuh dan anak diberikan hak untuk didengar pendapatnya oleh kedua orang tuanya. Penentuan kebebasan untuk menentukan (hak opsi) diputuskan melalui pengadilan atau melalui proses adat.

Perceraian selama ini seringkali menyisakan problem-problem, terutama persoalan hak-hak anak yang mencakup seluruh hak yang melekat pada anak yaitu hak memperoleh pendidikan, kesehatan, biaya pemeliharaan dan lain sebagainya. Sehingga pemenuhan hak-hak anak masih terdapat sebagian besar orang tua belum memenuhi hak-hak anak pasca perceraiannya. Akibat perceraian terkadang hak-hak anak ada yang dikesampingkan, terutama yang berkaitan dengan hak-hak pokok anak yaitu biaya pemeliharaan, pendidikan, tempat tinggal dan fasilitas-fasilitas penunjang lainnya. ${ }^{5}$ Terlebih lagi ketika orang tuanya sudah memiliki keluarga baru sehingga memungkinkan berkurangnya waktu untuk memenuhi hak-hak anaknya. Meskipun orang tua sudah tidak lagi dalam satu keluarga akan tetapi persoalan hak-hak anak tetap menjadi tanggung jawab orang tua dan tidak boleh dialihkan kepada orang lain selain kedua orang tuanya.

Ada sebagian orang tua cenderung melalaikan tanggung jawabnya dalam memenuhi hak-hak anak, sehingga yang terjadi adalah anak seringkali dititipkan kepada keluarga terdekat ayah atau ibu. Tidak hanya itu, akibat dari perceraian selama ini psikologi anak mengalami perubahan. Sebagai dampaknya adalah anak jarang berkomunikasi dengan kedua orang tuanya, cenderung pendiam, malas, minder serta cenderung nakal dan sebagainya. Ini semua disebabkan karena adanya kurang perhatian orang tua terhadap hak-hak anaknya. Seperti halnya perkawinan yang menimbulkan hak dan kewajiban, perceraian membawa akibat-akibat hukum bagi kedua belah pihak dan juga terhadap anak-anak yang dilahirkan. ${ }^{6}$

Anak adalah titipan Tuhan yang harus dijaga dan dirawat oleh setiap orangtua. Anak adalah putra putri kehidupan, masa depan bangsa dan negara. Oleh karena itu anak memerlukan pembinaan agar dapat berkembang mental dan spiritualnya secara maksimal. ${ }^{7}$ Sesungguhnya anak adalah harta yang paling berharga bagi setiap orangtua. Baik ayah maupun Ibu, keduanya pasti ingin bersama-sama merawat dan membesarkan anaknya. Kenyataannya, tak selamanya orangtua mampu menjaga dan merawat anaknya secara bersamaan karena suatu alasan tertentu. Perceraian misalnya. Perceraian mengakibatkan anak menjadi korban. Bagi anak-anak yang dilahirkan, perceraian orang tuanya merupakan hal yang akan mengguncang kehidupannya dan akan berdampak buruk bagi pertumbuhan dan perkembangannya, sehingga biasanya anak-anak adalah pihak yang paling menderita dengan terjadinya perceraian orang tuanya ${ }^{8}$

\footnotetext{
Pasal.

${ }^{5}$ Republik Indonesia, Undang-Undang Nomor 1 Tahun 1974 tentang Perkawinan., op. cit.,

${ }^{6}$ Hadi Supeno, Menyelamatkan Anak (Jakarta: Graha Putra, 2010), hlm., 13.

${ }^{7}$ Darwan Prints dalam Iman Jauhari (1), Hak-Hak Anak dalam Hukum Islam (Jakarta: Pustaka Bangsa Press, 2003), hlm., 80

${ }^{8}$ Satria Effendi, Problematika Hukum Keluarga Islam Kontemporer (Jakarta:Kencana, 2004), hlm. 167
} 
Perceraian bukanlah halangan bagi anak untuk memperoleh hak pengasuhan atas dirinya dari kedua orang tuanya, satu hal yang menjadi ketakutan besar bagi seorang anak adalah perceraian orang tua, ketika perceraian terjadi anak akan menjadi korban utama. Orangtua yang bercerai harus tetap memikirkan bagaimana membantu anak untuk mengatasi penderitaan akibat perpisahan orang tuanya. Orang tua adalah orang pertama yang bertanggung jawab untuk membayarkan hak-hak anak keturunan mereka, sehingga meskipun kedua orang tua mereka memiliki ikatan atau sudah bercerai anak tetap berhak mendapatkan perhatian dari kedua anaknya, karena kewajiban orangtua adalah mengantarkan anak-anaknya dengan cara mendidik, membekali mereka ilmu pengetahuan, baik ilmu agama maupun umum, untuk bekal mereka di hari dewasa. ${ }^{9}$

Perlindungan Anak adalah segala kegiatan untuk menjamin dan melindungi Anak dan hak-haknya agar dapat hidup, tumbuh, berkembang, dan berpartisipasi secara optimal sesuai dengan harkat dan martabat kemanusiaan, serta mendapat perlindungan dari kekerasan dan diskriminasi. ${ }^{10}$ Menyadari demikian pentingnya anak dalam kedudukan keluarga, individu, masyarakat, bangsa dan negara maka negara mengatur melalui undang-undang hak-hak anak misalnya dalam, UndangUndang Nomor 1 Tahun 1974 tentang Perkawinan, Undang-Undang Nomor 4 Tahun 1979 Tentang Kesejahteraan Anak, Konvensi Hak Anak yang dituangkan dalam Kepres Nomor 36 Tahun 1990, Instruksi Presiden Nomor 1 Tahun 1991 tentang Kompilasi Hukum Islam, Undang-Undang Nomor 3 tahun 1997 Tentang Pengadilan Anak, Undang-Undang Nomor 39 Tahun 1999 tentang Hak Asasi Manusia, UndangUndang Nomor 23 Tahun 2002 tentang Perlindungan Anak. ${ }^{11}$

Seperti yang telah diuraikan sebelumnya bahwa hak asuh anak itu sendiri belum juga di atur dalam Undang-undang No.1 Tahun 1974 mengenai peralihan hak asuh anak pasca putusnya perkawinan dalam rumah tangga. Sehingga hal ini menimbulkan berbagai macam persoalan dalam praktek persidangan terutama pada kasus perceraian dimana suami atau istri menuntut terhadap hak asuh anak tersebut. Dimana salah satu pihak mungkin ada yang merasa lebih berhak untuk mengasuh anakanaknya. Baik itu ibunya, karena merasa ia yang mengandung dan melahirkan, atau ayahnya, karena merasa ia yang membiayai.

Berdasarkan hal yang telah diuraikan diatas, maka selanjutnya dapat timbul beberapa permasalahan. Adapun permasalahannya adalah sebagai berikut: 1) Analisis Putusan Majelis Hakim Terhadap Penetapan Hak Asuh Anak dengan menggunakan Hukum Adat Batak pada Putusan Nomor 282/Pdt.G/2014/PN.TNG? 2)Bagaimana Pemenuhan Hak Seorang anak pasca perceraian pada putusan Nomor 282/Pdt.G/2014/PN.TNG ?

\footnotetext{
${ }^{9}$ Ahmad Rofik, Hukum Perdata Islam Di Indonesia.,(Jakarta : Rajawali Pers, 2013) hlm. 189

${ }^{10}$ Republik Indonesia, Undang-undang No 23 Tahun 2002 tentang perlindungan anak ., Pasal. 1 ayat 2

${ }^{11}$ Mufidah, Ch, Psikologi Keluarga Islam Berwawasan Gender (Malang: UIN Press, 2008), hlm., 340-341.
} 


\section{PEMBAHASAN}

\section{Putusan Majelis Hakim Terhadap Penetapan Hak Asuh Anak dengan menggunakan Hukum Adat Batak pada Putusan Nomor 282/Pdt.G/2014/PN.TNG}

Dalam menentukan hak asuh anak, pasti terdapat kesukaran dalam menentukan pihak mana yang cakap atau berhak mendapatkan hak asuh anak setelah terjadinya perceraian terlebih lagi jika anak yang di perebutkan masih di bawah umur sudah pasti masing-masing pihak akan berusaha mendapatkan hak asuh anak tersebut. Karena tidak ada pedoman yang secara tegas mengatur batasan pemberian hak asuh bagi pihak yang menginginkannya, maka hakim dalam menjatuhkan putusannya akan mempertimbangkan antara lain pertama, fakta-fakta yang terungkap dipersidangan; kedua, bukti-bukti yang diajukan oleh para pihak; serta argumentasi yang dapat meyakinkan hakim mengenai kesanggupan dari pihak yang memohonkan hak asuh anak tersebut dalam mengurus dan melaksanakan kepentingan dan pemeliharaan atas anak tersebut baik secara materi, pendidikan, jasmani dan rohani dari anak tersebut. Semua ini dipertimbangkan oleh hakim semata- mata dilakukan demi kepentingan dan kemanfaatan dari si anak tersebut.

Pedoman dasar yang menjadi pertimbangan majelis hakim dalam memutus pemberian hak asuh anak adalah Yurisprudensi dan Pasal 105 Kompilasi Hukum Islam (KHI) yang menyatakan bahwa dalam hal terjadi perceraian :

a. Pemeliharaan anak yang belum mumayyiz atau belum berumur 12 tahun adalah hak ibunya.

b. Pemeliharaan anak yang sudah mumayyiz diserrahkan kepada anak untuk memilih diantara ayah atau ibunya sebagai pemegang hak pemeliharaan.

c. Biaya pemeliharaan ditanggung oleh ayahnya.

Tetapi ketentuan Kompilasi Hukum Islam nampaknya tidak efektif untuk dapat berlaku secara Universal, karena ketentuan tersebut nampaknya hanya mengikat bagi mereka yang memeluk agama Islam saja (yang perkaranya diperiksa dan diputus di Pengadilan Agama). Sedangkan Yurisprudensi menyatakan bahwa : "Mengenai perwalian anak, Ibu kandung yang lebih di utamakan, khususnya bagi anak-anak di bawah umur karena demi kepentingan kesejaheraan anak".

Putusan Pengadilan Negeri Tanggerang nomor 282/Pdt.G/2014/PN.TNG pada tanggal 14 mei 2014 dimenangkan oleh pihak Suami yaitu Harry Napitupulu. Didalam pertimbangannya, majelis hakim mengenai hak asuh anak yakni sebagai berikut : "Bahwa 2 orang anak-anak yang masih berada dibawah umur oleh karena kedua orang tuanya yaitu penggugat dan tergugat ikatan perkawinannya telah putus karena perceraian, maka hak untuk mengasuh,memelihara dan mendididik anak-anak tersebut diserahkan kepada tergugat sebagai ayah kandungnya".

Selain itu dengan melihat fakta menurut adat batak yang memiliki garis keturunan Patrilineal Murni yang artinya secara murni garis keturunan mengikuti lakilaki atau Ayahnya, yang secara konsisten sudah diterapkan, terbukti sebagai penerus marga dalam adat batak yang mengikuti keturunannya dari pihak laki-laki yang diberikan kepada ayahnya dan diturunkan ke anaknya sampai kecucunya dan seterusnya. Hal-hal seperti ini sudah di terapkan baik perkawinan itu dilaksanakan antara suku batak dengan suku lain karena menurut adat batak apabila telah dilangsungkannya perkawinan maka si Istri akan ikut kepada pihak suami.

Analisis yuridis dari permasalahan mengenai penetapan hak asuh anak yang menggunakan hukum adat batak menurut peneliti bukan lah suatu hal yang tepat, 
karena hukum itu harus bersifat adil dan mencari keadilan walaupun sebenarnya pengertian adil tidak bisa di gambarkan. Indonesia memang merupakan suatu Negara yang memiliki ragam Suku dan Budaya salah satunya adalah Hukum adat. Hukum adat memang termasuk kategori hukum yang tidak tertulis dan masih dipercayai oleh beberapa masyarakat tertentu. Tetapi di dalam hukum adat di Indonesia yang dinilai bertentangan dengan hukum lain dan mengesampingkan hak asasi manusia. Salah satunya penerapan Hukum Adat batak untuk menetapkan hak asuh anak pasca perceraian dalam putusan Nomor 282/Pdt.G/2014/PN.TNG.

Dalam penetapan hak asuh anak dibawah umur hakim biasanya menggunakan Kompilasi Hukum Islam (KHI) atau Yurisprudensi yang menjadi acuan dalam pemutusan hak asuh anak dengan di ikuti dengan melihat syarat-syarat di dalam Undang-Undang No 1 Tahun 1974 pada pasal 49 yang berbunyi ; "Salah satu orang tua dapat dicabut kekuasaanya terhadap seorang anak atau lebih untuk waktu yang tertentu atas permintaan orang tua lain, keluarga anak dalam garis lurus ke atas dan saudara kandung yang telah dewasa atau pejabat yang berwenang dengan keputusan pengadilan dalam hal-hal : (a) Ia sangat melalaikan kewajibannya terhadap anaknya (b) Ia berkelakuan buruk sekali."

Selain itu ada kalanya seorang ibu kehilangan haknya untuk melakukan pengurusan dan perawatan terhadap anaknya yang belum dewasa. Berdasarkan beberapa literatur hukum ditemukan beberapa alasan yang dapat mengakibatkan seorang ibu kehilangan hak asuh terhadap anaknya, yaitu:

1. Menjadi pemabok, pemadat, penjudi, dan lain sebagainya yang sukar disembuhkan;

2. Telah meninggalkan pihak lain tanpa izin dan tanpa alasan yang sah atau karena hal lain di luar kemampuannya

3. Mendapat hukuman penjara

4. Melakukan kekejaman atau penganiayaan berat yang membahayakan pihak lain

5. Alasan-alasan lain sehingga dikhawatirkan tidak dapat menjamin keselamatan jasmani dan rohani anak-anaknya.

Seorang ibu bisa saja kehilangan untuk mendapatkan haknya dalam penetapan hak asuh anak pasca perceraian jika terdapat unsur-unsur yang dapat merugikan dalam proses tumbuh kembang si anak, tetapi dalam kenyataanya dalam putusan pengadilan pada putusan nomor 282/Pdt.G/2014/PN.TNG tidak adanya salah satu unsur tersebut tetapi majelis hakim memutus dengan menggunakan hukum adat sehingga Ny. Agatha Prawito sebagai penggugat kalah dalam penetapan hak asuh anak. Hal ini merupakan bukan keputusan yang tepat karena hukum kita adalah hukum positif dan bisa mengakomodir hukum adat itu sendiri, selain itu menurut peneliti hukum adat sifatnya sama seperti Kompilasi Hukum Islam tidak bisa diterapkan secara Universal karena akan banyak menimbulkan pro dan kontra dalam penerapannya. Karena hukum adat masih ada yang mempunyai sifat mengesampingkan hak-hak seseorang salah satunya dalam adat batak.

Memang makna "anak" dalam ungkapan "anakhon hi do hamoraon di au", lebih condong dialamatkan pada keberhasilan anak laki-laki semata, karena diharapkan sebagai "anak siboan marga" (penerus marga). Jadi peran seorang anak khususnya anak laki-laki adalah hak mutlak untuk ayah dan keluarga ayahnya. Dalam hal ini Peneliti dapat mengambil kesimpulan bahwa seorang perempuan dalam adat batak terintervensi karena adanya perbedaan Gender yang terjadi, dimana status dan kedudukan sang lakilaki lebih di istimewakan dari pada hak seorang istri. Dengan adanya perbedaan gender 
seperti ini dapat membuat seorang perempuan tersiksa baik itu secara fisik maupun psikologisnya (batinnya). Selain itu ini merupakan salah satu bentuk "konspirasi" adat dari nenek moyang kita sampai sekarang, yang tertuang dalam aturan-aturan baku adat batak/patrilineal (lingkungan sosial otonom, meminjam istilah Sally Falk Moore) yang secara terus-menerus kita ikuti dan tanpa sadar kita terjerumus dalam suatu doktrinasi negatif. Posisi perempuan dikondisikan dibawah dominasi kaum pria, bahkan sama sekali tidak diberikan suatu porsi dalam adat sehari-hari, dan malah cenderung sebagai pelengkap pria saja.

Convention the Elimination of All Forms of Discrimination against Women, tanggal 18 Desember 1979, yang diratifikasi oleh Indonesia dengan dikeluarkannya Undang-Undang No. 7 Tahun 1984 tentang Pengesahan Konvensi Mengenai Penghapusan Segala Bentuk Diskriminasi Terhadap Wanita. Dalam Pasal 2 disebutkan "Negara peserta konvensi mengutuk diskriminasi terhadap wanita dalam segala bentuknya dan bersepakat untuk menjalankan dengan segala cara yang tepat dan tanpa ditunda-tunda, kebijaksanaan menghapus diskriminasi terhadap wanita, dan untuk tujuan itu berusaha: (a) mencantumkan asas persamaan antara pria dan wanita dalam Undang-Undang Dasar Nasional mereka atau perundang-undangan yang tepat lainnya, jika belum termasuk di dalamnnya dan untuk menjamin realisasi praktis dari asas ini, melalui hukum dan cara-cara lain yang tepat; (b) membuat peraturan perundangundangan yang tepat dan peraturan lainnya termasuk sanksi-sanksinya dimana perlu, melarang semua diskriminasi terhadap wanita; (c) membuat peraturan-peraturan yang tepat untuk menghapus perlakuan diskriminasi terhadap wanita oleh setiap orang, organisasi atau perusahaan; (d) membuat peraturan-peraturan yang tepat, termasuk pembuatan undang-undang, peraturan-peraturan, kebiasaan-kebiasaan, dan praktikpraktik yang diskriminatif terhadap perempuan”.

Ketentuan Undang-Undang No. 39 Tahun 1999 Tentang Hak Asasi Manusia, Pasal 51 ayat (1) "seorang istri selama dalam ikatan perkawinan mempunyai hak dan tannggung jawab yang sama dengan suaminya atas semua hal yang berkenan dengan kehidupan perkawinannya, hubungan dengan anak-anaknya, dan hak pemilikan serta pengelolaan harta bersama"; ayat (2) "setelah putusnya perkawinan, seorang wanita mempunyai hak dan tanggung jawab yang sama dengan mantan suaminya atas semua hal yang berkenan dengan anak-anaknya, dengan memperhatikan kepentingan terbaik bagi anak"; ayat (3) "setelah putusnya perkawinan, seorang wanita mempunyai hak dan tanggung jawab yang sama dengan mantan suaminya atas semua hal yang berkenan dengan harta bersama tanpa mengurangi hak anak, sesuai dengan ketentuan peraturan perundang-undangan".

Amanat konvensi dan Undang-Undang No. 7 Tahun 1984 telah jelas menghapuskan segala bentuk diskriminasi, dengan mengedepankan asas persamaan dalam hukum (equality before the law), dengan pengertian juga dalam adat sebagai hukum yang tidak tertulis. Asas mana telah diterima di seluruh dunia sebagai asas yang berlaku universal. Tidak hanya itu, asas keadilan sesungguhnya mengilhami asas persamaan, dengan demikian kita akan mampu melihat diskrimasi itu bukan merupakan takdir yang tidak bisa dilawan kaum perempuan.

Dengan pengesahan Konvensi Mengenai Penghapusan Segala Bentuk Diskriminasi Terhadap Wanita dan Undang-undang Hak Asasi Manusia tersebut seharusnya para sesepuh dan para petua Batak berpikir ulang dan mengkaji asas dan prinsip yang diskriminatif itu, sehingga persamaan antara wanita dan pria dikedepankan baik dalam keluarga, adat, dan dalam semua kehidupan sosial batak. Berat memang dan bahkan dilematis jika kita membuat suatu perubahan yang sangat revolusif, bahkan tidak sedikit yang menolak ide ini. Namun, pro dan kontra kita 
jadikan sebagai kazanah untuk memperkaya ide pemikiran dan menemukan suatu kebenaran yang hakiki tanpa merugikan bahkan memojokkan yang lain. Semua elemen harus duduk bersama untuk membicarakannya, sehingga hasil yang dicapai memuaskan semua pihak.

Dalam budaya batak sayangnya masih belum banyak yang dapat dengan sungguh-sungguh melihat, bahwa keberadaan perempuan dan laki-laki itu sama karena seorang perempuan di ciptakan dengan tulang rusuk laki laki yang artinya bahwa perempuan tidak bisa di posisikan di atas laki-laki serta juga tidak bisa dibawah lakilaki maka dari itu perempuan kedudukannya harus sejajar karena untuk mendampingi laki-laki. Harapan dimasa yang akan datang sebenarnya Budaya Batak sama seperti budaya pada suku-suku lainnya mempunyai inti. Inti dari adat dan budaya adalah harmoni, keseimbangan, kebersamaan dan cita-cita hidup yang luhur. Inti budaya ini perlu diterjemahkan ke dalam situasi masyarakat masa kini, dimana pengarusutamaan gender sedang berlaku. Dengan demikian, suatu saat adat itu bukan sebagai penghambat dan momok bagi perempuan tetapi menjadi bagian hidup dan cara hidup dari perempuan dan laki-laki. Terciptanya adat dan budaya yang ramah kepada perempuan bukan adat dan budaya yang menghukum dan menghakimi perempuan, inilah harapan ke depan. Dengan demikian semakin banyak perempuan memperoleh kesadaran yang kritis terhadap kehidupan yang dilaluinya serta mempunyai kesanggupan untuk mengubahnya.

Dalam hal ini perlu adanya pendidikan yang formal dan informal khusus kepada perempuan, yang berorientasi pada kesetaraan gender. Gereja merupakan sebagai bagian yang integral diharapkan berperan sangat aktif di dalam mengabarkan berita pembebasan tentang kekerasan budaya yang dialami perempuan dalam hidupnya. Meski terkadang ajaran agama (Kristen) dianggap lebih mengajarkan kesamaan dan keadilan keberadaan laki-laki dan perempuan, artinya bebas dari nilai-nilai diskriminatif terhadap perempuan, namun didalam kenyataan hidup berjemaat, terlihat beragam interpretasi terhadap ajaran Kristen atau ayat-ayat Alkitab yang justru menjadi dasar untuk tindakan diskriminatif dan kekerasan terhadap perempuan baik yang terselubung maupun yang terlihat nyata. Dalam hal ini, gereja diharapkan bukan saja berkhotbah tentang bagaimana perempuan menjadi istri yang baik, tetapi juga berkhotbah untuk menyadarkan warga jemaat tentang penghapusan kekerasan terhadap perempuan. Sebagai orang Batak yang hidup karena kasih Tuhan, telah ditebus oleh pengorbanan Kristus dan mampu hidup benar hanya dalam terang Firman Tuhan, sudah selayaknya kita menelaah ulang perlakuan dan sikap-sikap diskriminatif yang selama ini diberlakukan terhadap laki-laki dan perempuan. Semoga harapan ini bisa segera terwujud untuk menjawab pergumulan para perempuan-permpuan pada umumnya serta perempuan Batak khususnya.

Dalam kasus penetapan hak asuh anak sebaiknya tidak melupakan asas equality before the law, karena pada hakikatnya kedudukan suami istri itu sama tidak bisa tebang pilih begitu saja karena adanya hukum adat yang mempunyai sifat diskriminasi terhadap kaum perempuan, mungkin harus adanya pengakuan terhadap persamaan hak dan kedudukan antara laki-laki dengan perempuan, sehingga dalam penerapan asas persamaan di hadapan hukum memang harus dimaknai sebagai persamaan terhadap subjek dengan kondisi yang sama, dilihat dari kesuluran proses penegakan hukum itu sendiri, mulai dari proses, perlakuan hingga putusan semuanya harus diputuskan seadil-adilnya karena hakekat yang di pandang penting ialah perlakuan seseorang harus dianggap sama, tidak memandang status apapun, kondisi apapun terhadap sumber yang sama. 


\section{Pemenuhan Hak Seorang Anak pasca perceraian pada putusan Nomor 282/Pdt.G/2014/PN.TNG}

Hakikat Putusan adalah sebagai sarana penyelesaian sengketa karena ketidakmampuan para pihak untuk menyelesaian sendiri sengketa yang terjadi. Pengertian diatas adalah hakikat putusan secara umum untuk perceraian putusan diperlukan karena menjadi syarat putusannya perkawinan sesuai kentuan UndangUndang Perkawinan. Putusan Pengadilan Negeri Bekasi NO.350/PDT.G/2013/PN.BKS adalah putusan perceraian, namun yang lebih di sorot dalam penelitian penulis adalah fakta hukum dalam pertimbangan hukum hakim.

Pengadilan telah menjalankan tata prosedur yang benar dalam peradilan sehingga ketidakhadiran oleh pihak terghugat bukan menjadi kelalaian pengadilan dan pengadilan hanya akan melanjutkan perkara ketahap berikutnya dengan memfokuskan pada keterangan-keterangan penggugat. Dalam kasus perceraian seperti ini di perbolehkan karena yang di butuhkan oleh pengadilan adalah keberhasialan pihak penggugat untuk membuktikan dalil-dalilnya yang menjadi alasan perceraian. Ketentuan berlaku berbeda jika penggugat adalah pihak yang tidak menghadiri pengadilan maka gugatan di anggap gugur dan penggugat di hukum biaya perkara sesuai dengan bunyi pasal 124 HIR karena seharusnya yang berperkara memiliki tanggung jawab penuh untuk proses persidangan yang di perkarakannya.

Pertimbangan Majelis Hakim mengabulkan permohonan tersebut karena dalam pernikahan terdapat antara lain pendaftaran, mempelai putra dan putri, wali mempelai putri, dua orang saksi, mahar, adanya ijab dan qabul dari wali wali mempelai putri dengan mempelai putra, adanya kerelaan/persetujuan kedua belah pihak, telah tercapainya usia nikah bagi kedua mempelai, tidak ada larangan antara mempelai putra dan mempelai putri, sehingga pernikahan tersebut memenuhi syarat-syarat menurut hukum agama dan perundangan yang berlaku khususnya Pasal 2 ayat (1) dan Pasal 6 ayat (1), (7), dan (8) Undang-Undang Nomor 1 Tahun 1974 tentang Perkawinan serta Pasal 10 ayat (1), (2), dan (2) Peraturan Pemerintah Nomor 9 Tahun 1975. Kemudian terkait ketidakhadiran secara fisik mempelai putra di tempat mempelai putri atau walinya yang mengijabkan, tidak mengurangi sahnya pernikahan berdasarkan dalildalil sesuai dengan ahli Fiqih dalan Fiqhus Sunah halaman 34 jilid II. ${ }^{12}$

Apabila suatu perkawinan tidak dicatatkan, hal ini tidak akan membatalkan suatu perkawinan akan tetapi suami-istri tersebut tidak memiliki bukti otentik bahwa mereka telah melaksanaan suatu perkawinan yang sah. Akibatnya, dilihat dari aspek yuridis, perkawinan tersebut tidak diakui pemerintah, sehingga tidak mempunyai kekuatan hukum (no legal force), yang mana perkawinan tersebut tidak dilindungi hukum. ${ }^{13}$

Pengajuan perceraian kepada hakim dari perkawinan yang tidak dicatatkan, tidak membuat hakim boleh untuk menolak memeriksa, mengadili dan memutus perceraian dengan dalil perkawinan tersebut dianggap tidak pernah dengan berasaskan ius curia novit yang memberi kewajiban pada hakim harus tetap memeriksa, mengadili dan memutuskan perkara perceraian tersebut, hal ini adalah penerapan dari Pasal 10 ayat (1) Undang-undang Nomor 48 Tahun 2009 tentang kekuasaan kehakiman.

\footnotetext{
12 Penetapan Pengadilan Agama Kota Jakarta Selatan Nomor 1751/P/1989 perihal Keabsahan Perkawinan Jarak Jauh, tanggal 18 Mei 1990.

${ }^{13}$ Anshary MK, Hukum Perkawinan di Indonesia, Masalah-masalah Krusial, (Yogyakarta: Pustaka Pelajar, 2010), 29-30.
} 
Dasar putusannya perkawinan tersebut karena perceraian juga di dukung dengan Putusan Mahkamah Agung yang telah menjadi Yurisprudensi yaitu putusan Nomor $1776 \mathrm{~K} / \mathrm{Pdt} / 2007$ yang menerangkan bahwa perkawinan yang dilakukan secara adat dan tidak dicatatkan pada catatan sipil di pandang tetap sah. Penggugat dan tergugat dalam putusan ini juga disamping melakukan perkawinan menurut upacara gereja katolik di Paling (Sanggu Ledoo) pada tanggal 18 april 1982 sesuai dengan ketentuan dalam pasal 2 ayat (1) Undang-Undang Perkawinan juga melakukan perkawinan secara adat dayak yang di ketahui oleh Kepada Desa Sango Kepala Benua Riuk dan saksi-saksi.

Hakim sebagai salah satu aparat yang diberi wewenang untuk melaksanakan kekuasaan kehakiman dalam mempergunakan putusan hakim lain di sebabkan oleh beberapa pertimbangan yaitu diantaranya adalah pertimbangan psikologis karena keputusan hakim mempuyai kekuatan/kekuasaan hukum terutama kepada keputusan pengadilan tinggi dan mahkamah agung, maka biasanya hakim bawahan segan untuk tidak mengikuti putusan tersebut. Yang kedua adalah pertimbangan praktis karena dalam kasus yang sama sudah pernah di jatuhkan putusan oleh hakim terdahulu lebihlebih apabila putusan itu sudah dibenarkan/diperkuat oleh pengadilan tinggi dan mahkamah agung maka akan lebih praktis apabila hakim berikutnya memberikan putusan yang sama. Disamping itu apabila keputusan hakim yang tingkatnya lebih rendah memberi keputusan yang menyimpang/berbeda dari kepurtusan hakim yang lebih tinggi maka keputusan tersebut tentu tidak dapat dibenarkan pada waktu putusan itu di mintakan banding. Ketiga adalah karena hakim yang bersangkutan sepedapat dengan keputusan hakim lain yang lebih dahulu terutama apabila isi dan tujuan Undang-undang sudah tidak sesuai dengan keadaan sosial yang nyata pada waktu kemudian maka sudah sewajarnya apabila keputusan hakim lain tersebut dipergunakan. ${ }^{14}$ Menurut penulis ada beberapa cara untuk menerima dan mengabulkan perceraian seperti pada contoh kasus Nomor Putusan 350/Pdt.G/2013/Pn.Bks.

\section{KESIMPULAN}

Analisis terhadap putusan majelis hakim yang didasarkan menggunakan hukum adat bukanlah suatu keputusan yang tepat, karena dalam penetapan hak asuh anak di bawah umur yang di utamakan adalah seorang ibu. Apabila ibu tidak mendapatkan hak asuh harus memenuhi beberapa unsur di dalam Undang-Undang Perkawinan dan UndangUndang Perlindungan anak mengenai hal-hal yang dapat mempengaruhi tumbuh kembang si anak tetapi di dalam putusan 282/Pdt.G/2014/PN.TNG Penggugat sebagai seorang ibu tidak memenuhi unsur-unsur tersebut dan majelis Hakim memutus hak asuh anak menggunakan hukum adat batak dimana mempunyai sifat-sifat yang mengesampingkan hak-hak seorang orang perempuan. Pada dasarnya kedudukan lakilaki dan Perempuan memiliki kedudukan yang sama sesuai dengan asas equality before the law sehingga kedudukan seseorang memiliki kedudukan yang sama di hadapan hukum.

Pemenuhan hak asuh anak didalam putusan 282/Pdt.G/2014/PN.TNG terhadap seorang ayah tidak akan berjalan secara lancar karena di dalam hukum adat batak tidak ada aturan yang mengatur mengenai pemenuhan terhadap hak dan kewajiban seorang anak. Karena dalam adat batak hanya mengatur penetapan hak asuh anaknya saja tidak dengan pemenuhan hak dan kewajiban terhadap seorang anak. Sehingga pemenuhan

${ }^{14}$ R. Soeroso, Yurisprudensi Hukum Acara Perdata 5 Tentang Putusan Pengadilan (Jakarta: Sinar Grafika, 2012), xxxiii. 
hak asuh anak dalam putusan tersebut hanya terpenuhi secara materil saja tetapi anak tidak mendapatkan kasih sayang secara sepenuhnya karena pada hakekatnya seorang anak berhak untuk hidup dan di asuh oleh orangtuanya sendiri sesuai dengan UndangUndang Perlindungan Anak.

\section{SARAN}

Dalam proses penerapan hukum pada perkara penetapan hak asuh anak sebaiknya ditinjau terlebih dahulu mengenai hukum positif yang berlaku karna dalam penerapan hukum adat masih banyak pihak-pihak yang dirugikan dengan dikesampingkannya hak seseorang karena adanya hukum adat itu sendiri.

Pemenuhan hak dan kewajiban seorang anak merupakan tanggung jawab orang tua karena orang tua mempunyai tanggung jawab yang lebih terhadap seorang anak karena anak merupakan korban dari perceraian seharusnya orang tua juga bisa mempertanggung jawabkan terhadap pemenuhan hak asuh anak tersebut.

\section{DAFTAR PUSTAKA}

\section{Buku}

AF Hasanuddin, Pengantar Ilmu Hukum, Jakarta: Pustaka Al-Husna Baru, 2004

Effendi Satria, Problematika Hukum Keluarga Islam Kontemporer, Jakarta:Kencana, 2004

Ghozali Abdul Rahman, Fiqh Munakahat. Jakarta: Prenada Media Group, 2003

Hadikusuma Hilman, Hukum Perkawinan Indonesia Menurut: Perundangan, Hukum Adat,Hukum Agama, Bandung: Mandar Maju,1990

Hadikusuma Hilman, Hukum Perkawinan Indonesia, Bandung: CV. Mandar Maju, 2007

Ibrahim Johnny, Teori dan Metodologi Penelitian Hukum normatif, Malang ; Banyumedia Publishing, 2006

Ishaq, Dasar-Dasar Ilmu Hukum. Jakarta : Sinar Grafika,2008

K.Wantjik Saleh, Hukum Perkawinan Indonesia, Jakarta: Ghalia Indonesia, 1982

Latif, M Djamil, Pineka Hukum Perceraian di Indonesia, Jakarta : Ghalia Indonesia,cet.2, 1985

M Philipus Hadjon, Perlindungan Bagi Rakyat diIndonesia, PT.Bina Ilmu,Surabaya, 1987

Moelino, Anton M, Kamus Besar Bahasa Indonesia, cetakan ke 2, Jakarta. Balai Pustaka, 1988

Mufidah, Psikologi Keluarga Islam Berwawasan Gender Malang: UIN Press, 2008

Nasir M Djamil, Anak Bukan Untuk Dihukum, Sinar Grafika, Jakarta, 2013 
PNH.Simanjuntak, Pokok-Pokok Hukum Perdata Indonesia, Jakarta: Pustaka Djambatan, 2007

Prawirohamidjojo Soetoyo \& Pohan Maretha, Hukum Orang dan Keluarga, Surabaya; Airlangga University Press, 2000

Prawirohamidjojo Soetoyo \& Safioedin Azis, Hukum Orang Dan Keluarga, Bandung: Alumni, 1986

Prints Darwan, dalam Iman Jauhari, Hak-Hak Anak dalam Hukum Islam. Jakarta: Pustaka Bangsa Press, 2003

Prodjodikoro Wiryono. Hukum Perkawinan di Indonesia, Bandung : Sumur, 1984

Raharjo Satjipto, Ilmu Hukum. Bandung : PT. Citra Aditya Bakti, 2000

Rofik Ahmad, Hukum Perdata Islam Di Indonesia.,Jakarta : Rajawali Pers, 2013

Soerjono Soekanto \& Mamudji,S. Penelitian hukum normatif suatu tinjauan singkat, Jakarta; rajawali press, 2011

Soekanto Soerjono, Pengantar Penelitian Hukum, Jakarta UI-Press, 1986

Subekti R, Pokok-Pokok Hukum Perdata, Jakarta : Internusa, 2003

Sudiyat Iman, Asas-Asas Hukum Adat bekal pengantar, Yogyakarta ; Liberty, 1981

Supeno Hadi, Menyelamatkan Anak. Jakarta: Graha Putra, 2010

Syarifin Pipin, Pengantar Ilmu Hukum, Bandung : CV. Pustaka Setia, 2009

Syatifuddin Amir, Hukum Perkawinan Islam, Jakarta; Preriada Media, 2007

Thalib Sajuti, Hukum Keluarga Indonesi. Jakarta : Universitas Indonesia, 1986

Triwulan Titik, Hukum Perdata dalam Sistem Hukum Nasional, Jakarta: Kencana,2008

Wignjodipoegoro Soerjono, Pengantar Dan Asas-asas Hukum Adat, Jakarta : Penerbit CV Haji Masangung

\section{Peraturan Perundang-Undangan}

Republik Indonesia, Undang-Undang Tentang Perkawinan, UU No.1 Tahun1974

Republik Indonesia, Undang-Undang Tentang Perlindungan Anak, UU No. 23 Tahun 2002

Republik Indonesia, Undang-Undang Tentang Perlindungan Anak, UU No. 35 Tahun 2014

Republik Indonesia, Undang-undang Tentang kesejahteraan Anak, UU No 4 Tahun 1979.

\section{Internet}

https://media.neliti.com/media/publications/162641-ID-perlindungan-hukumterhadap-anak-di-bawa.pdf

https://sitorusdori.wordpress.com/2013/12/01/perceraian-sirang-dalam-perspektifadat-batak/

http://raypratama.blogspot.co.id/2015/04/teori-perlindungan-hukum.html. 